УДК 338.486.1:338.48-61(045)

DOI: 10.31339/2617-0833-2019-2(27)-12-17

БАЗОВИЙ МЕНЕДЖМЕНТ ПОДІЕВОГО ТУРИЗМУ

Зеленська Л.В., Шандор Ф.Ф.

\title{
BASIC EVENT TOURISM MANAGEMENT
}

Zelenska Liliia, Shandor Fedir

У статті вказано актуальність розробки та просування позитивного образу Украӥни та територіальних брендів ї̈ регіонів як за кордоном, так $i$ всередині краӥни за рахунок видовищних дійств. Підвищення привабливості регіону і формування ефективного організаційно-економічного механізму розвитку потребує діючої системи менеджменту подієвого туризму.

Ключові слова: подієвий туризм, фестивальний туризм, менеджмент туризму, організація туристичних заходів.

The article describes the urgency of developing and promoting the positive image of Ukraine and territorial brands of its regions both abroad and domestically through spectacular actions. Increasing the attractiveness of the region and forming an effective organizational and economic development mechanism requires an effective event tourism management system.

According to experts of the World Tourism Organization, one of the new dynamically developing destinations is event tourism, which ranks second in popularity in Europe at the expense of established traditions, ethno-cultural and historical heritage. In countries such as Germany, Italy, France, Spain, Hungary, event tourism is regarded as a priority area of tourism. It is a highly profitable type of tourism that contributes to the growth of tourist flows, the creation of modernized infrastructure and the promotion of territories. Experts say that the most popular topics of organized events in the future will be extreme sports, spectacular martial arts and outdoor events.

Key words: event tourism, festival tourism, tourism management, organization of tourist events.

Одним із нових напрямків, що динамічно розвивається, за оцінкою експертів Всесвітньої туристичної організації, є подієвий (event) туризм, який займає друге місце по популярності в Європі за рахунок сформованих традицій, етно-культурної та історичної спадщини. В таких країнах як Німеччина, Італія, Франція, Іспанія, Угорщина подієвий туризм розглядається як пріоритетний напрямок туристичної діяльності. Це високоприбутковий вид туризму, який сприяє росту туристичних потоків, створення модернізованої інфраструктури та просуванню територій. Експерти говорять, що найбільш популярними темами організованих заходів в майбутньому будуть екстремальні види спорту, видовищні єдиноборства та фестивальні дійства на відкритому повітрі.

Історія подієвого туризму налічує століття, але лише останні десятиліття науковці виокремили його в самостійну галузь. Впровадження відбувається досить повільними темпами на регіональному рівні за рахунок проведення культурних, освітніх, спортивних та інших заходів, переважно, у великих містах. Подієвий (event) туризм відповідає потребі людей стати частиною подій, впливати на їх хід та піти з радісним відчуттям приналежності до чогось масштабного. Наразі актуальним питанням є розробка та впровадження Програми створення та просування позитивного образу України та територіальних брендів ії регіонів як за кордоном, так і всередині країни.

Проблеми менеджменту подієвого туризму в Україні не розглядаються в науковій літературі належним чином. Проте певні питання розглядалися такими вченими як: Бейдик О.О., Бабкін А.В., Устименко Л.М., Власенко О.Б., Забалдіна Ю.Б., та інші. Вони вказують на необхідність включати подієвий менеджмент як елемент привабливості туристично- 
рекреаційної території, проводити аналіз становлення та розвитку в окремих регіонах та в Україні в цілому, а також, що впливає на ефективну організацію та проведення видовищних дійств.

Мета статті: аналіз основних складових менеджменту подієвого туризму, особливості його впровадження задля розвитку перспективного сегменту туристичного ринку.

Вперше термін «подієвий туризм (event tourism)» був використаний у 80-роках 20 століття, коли заходи були спрямовані на масового глядача. Участь спонсорської підтримки була обмежена і всі присутні та учасники повинні були приймати ті, умови, що їм надавались. Подієвий туризм - це неперевершена атмосфера свята, індивідуальні умови відпочинку і незабутні враження. Головна особливість подієвого туризму - безліч яскравих неповторних моментів [2]. XXI століття характеризується динамічними змінами усіх сфер людського життя, туризм не є виключенням. Групу людей вже не можна оцінювати масово, те, що колись було однорідним суспільством все більше і більше сегментується в залежності від демографічних особливостей, стилю життя і відпочинку, виду зайнятості, корпоративних переваг та інших факторів. Демасифікація - це розподілення населення по достатньо невеликим групам, які відрізняються один від одного за різними характеристиками. Період «хліба і видовищ» закінчився, даючи місце модернізованим видам туристичної діяльності, спеціально підібраних для кожного окремого сегменту суспільства.

Останнім часом ефект глобалізації міжнародного туризму привів до постійної диференціації між популярними напрямами та пошуку оптимальних видовищних дійств для кожного учасника туристичного процесу. В такій ситуації подієвий туризм виступив як істотний елемент в розвитку туристичних дестинацій, залученні споживачів, пошуку інвестицій та покращенні локального і регіонального рівня економіки [6].

Даний вид туризму не підлягає традиційному кількісному вимірюванню. Можна говорити лише про міру впливу подієвих ресурсів на створення туристичної інфраструктури, формування туристичних потоків, яка у нинішньому світі, насамперед, залежить від реклами події та піар-акцій навколо неї. Це вказує на те, що «подія», яка використовується у туризмі величезною мірою залежить від суспільних вподобань, від моди й уяви про престижність заходу. Велике значення має постійність і періодичність проведення заходів [5].

Базовим компонентом подієвого туризму є подія (event) - запланована соціальносуспільна подія (захід), що відбувається в певний час, із певною метою та має певний резонанс для суспільства і є приводом для туристичної подорожі. Значення усіх заходів полягає в тому, що вони є важливим мотивуючим фактором в туризмі, який стимулює продажі багатьох туристичних напрямів. Крім того їх використання дає можливість уникнути такої гострої для туристичної сфери проблеми, як сезонний чинник. Планування та створення подієвих турів розпочалося лише кілька десятиліть тому і було зумовлене зростанням попиту споживачів на нові враження від таких подій, як, зокрема, фестивалі, карнавали, спортивні змагання. Індустрія подієвого туризму є галуззю, яка динамічно розвивається в наш час $\mathrm{i}$ створює значну кількість робочих місць. Крім того, події грають іншу важливу роль культурний розвиток, зміцнення національних та релігійних ідей, наукова пропаганда та духовний відпочинок [1].

Підвищення привабливості подієвого туризму та формування ефективного організаційно-економічного механізму розвитку потребує діючої системи управління подією. Багато науковців розглядають менеджмент подій як практичне застосування менеджменту в області проектування проведення та організації заходів. Отже, менеджмент подієвого туризму можна розглянути як практичне застосування управлінських рішень 3 метою створення привабливої події на туристично-рекреаційній території. В iï основу покладено обгрунтована послідовність виконання певних дій з планування, організації, координації, контролю реалізації видовищного дійства, а також управління групою виконавців цих дій.

Менеджмент — це один із найдавніших видів діяльності людини. Потреба в 
управлінні, тобто в менеджменті виникла приблизно 7 тис. років тому, коли людина почала здійснювати колективну господарчу діяльність. Менеджмент - це процесс координування й об'єднання робочої діяльності інших людей. Термін “менеджмент” $\epsilon$ вужчим від “управління", адже менеджмент застосовується на підприємствах і в організаціях, а управляють також державою, суспільством, технологічними системами, процесами тощо [3].

Менеджмент подієвого туризму поступово стає окремою підсистемою менеджменту туристичних дестинацій різного рівня, його об єктом виступають заходи (events), спрямовані на залучення туристів. А невід ємними функціями - планування, організація та керівництво такими подіями в рамках єдиної концепції місцевого туристичного продукту [4]. Цільова аудиторія подієвого туризму - це забезпечені туристи з доходом вище середнього, а також компанії, що складаються з декількох осіб. Подієвий туризм можна класифікувати за масштабом події (національного або міжнародного рівня) та за тематикою події: ярмарки та виставки; паради; карнавали; фестивалі; освітні заходи; театралізовані шоу; національні свята.

Заплановані заздалегідь події є просторово-тимчасовим, унікальним явищем, яке під час взаємодії зі споживачами туристичних послуг створює популярний туристичний продукт. Найбільш привабливою частиною подій $є$ те, що вони ніколи не бувають однаковими, тому кожен турист прагне відвідати захід самостійно, щоб повністю зануритися в цей унікальний досвід [6]. Потрібно зауважити, що туристична індустрія досить багатогранна та належить до галузей невиробничої сфери, а іï функціонування характеризується високим рівнем суспільно-економічних вимог де всі елементи взаємопов язані та взаємозалежні (Рис.1)

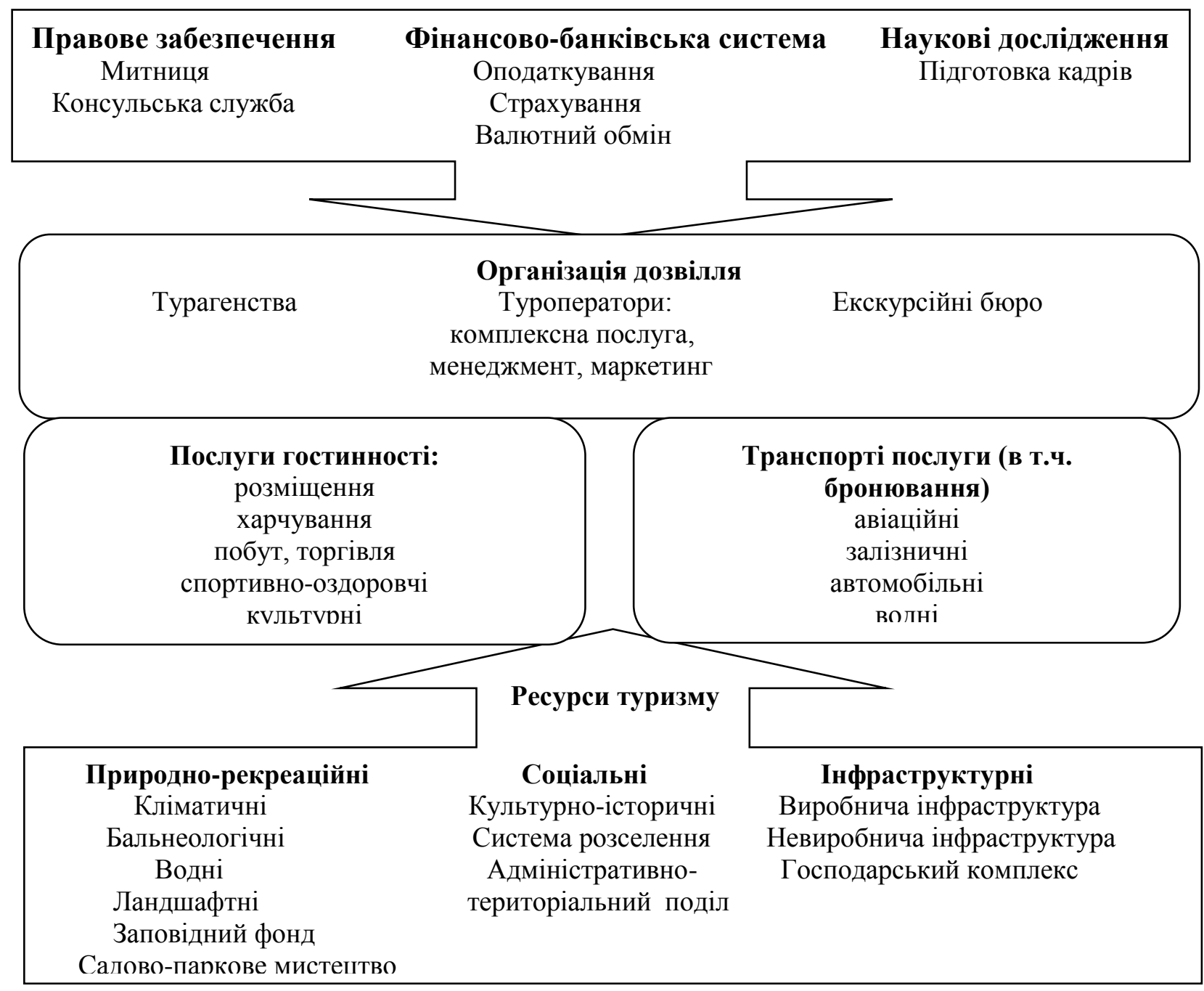

Рис. 1. Елементи індустрії туризму 
Менеджмент подієвого туризму включає вивчення особливостей, що безпосередньо впливають на проведення заходів:

- бренд;

- цільова аудиторія;

- розробка концепцій події;

- логістичне планування;

- координація технічних аспектів.

Ефективність подієвого менеджменту забезпечується застосуванням певних принципів, які охарактеризовано в рисунку 2.

\begin{tabular}{|c||c|}
\hline \multicolumn{1}{|c|}{ Управлінські рівні } & Суб’скти, що застосовують подісвий менеджмент \\
\hline Мікрорівень & Туроператори, турагенства \\
\hline Мезорівень & Туристичні дестинації, органи місцевого самоврядування \\
\hline Макрорівень & Органи державної влади \\
\hline Глобальний рівень & Міжнародні організації \\
\hline
\end{tabular}

Рис. 2. Управлінські рівні суб'сктів подісвого менеджменту

Ефективність подієвого менеджменту забезпечується застосуванням певних принципів:

1) етичні принципи відображають дотримання вимог, які окреслюють систему загальних цінностей та уподобань суспільства, правил етики у практичній роботі менеджерів подієвого туризму;

2) принципи цілісності - усе те, що планується та здійснюється в межах події має керуватися цілями іiі успішної реалізації;

3) принцип суб'єктивного підходу означає, що кожний захід має свої особливості, зумовлені місцем, часом, визначеними завданнями, складом учасників, баченням проблеми замовниками та виконавцями;

4) принцип медійності. Всі події, здійснювані в рамках подієвого менеджменту, повинні широко висвітлюватись, зокрема, засобами масової інформації як до початку події, так і після ії закінчення;

5) принцип ефекту впливу означає, що подія обов'язково має бути привабливою, викликати в аудиторії позитивні емоції своєю незвичайністю, художнім оформленням;

6) принцип масовості. Подія має бути масовим заходом і мати підтримку значної кількості прихильників, що закликають до подальшого розширення числа учасників події;

7) принцип забезпеченості, тобто мають бути надані всі необхідні ресурси (матеравльно-технічні, фінансові, кадрові);

8) принцип ефективності визначається на основі оцінки збільшення потоку туристів, а також впливу події на розвиток інших галузей, таких як транспорт, торгівля, готельноресторанний бізнес [4].

Менеджери заходів зацікавлені в розвитку туристичного потенціалу подієвого туризму, оскільки існує багато проблем у цій сфері, зокрема домінування декількох «знакових» подій, які тримають основну масу ринку та стали постійними, що зумовило ігнорування місцевих та регіональних дійств. Також існує проблема надмірних торгів під час проведення події. Менеджери подієвого туризму повинні більше уваги приділяти 
ознайомленості туристів зі спектром послуг, які можуть бути запропоновані під час проведення заходу [7].

Потрібно зазначити, що подієвий туризм є перспективним видом, який оперує невичерпним ресурсним потенціалом. Проте, державне регулювання та підтримка поки що відсутня, не розроблені маркетингові заходи, для просування на вітчизняний та міжнародний туристичний ринок.

Науковці туристичної сфери працюють над великою кількістю проблем, невелика їх частка пов'язана безпосередньо з подієвим туризмом, його організацією та просуванням, тому необхідно намагатися знайти відповіді на низку актуальних питань. Які події найбільш ефективно використовувати для отримання максимально високого прибутку регіону чи туристичної території; чи здатні події локального масштабу повернути всі вкладені в них інвестиції; як довго певні види подій зможуть тримати увагу публіки та збирати велику кількість споживачів; які ризики можуть бути пов'язані з проведенням подієвих турів; як зберегти навколишнє середовище від масового напливу туристів тощо.

\section{Список використаних джерел}

1. José Manuel Hernández-Mogollón Event tourism analysis and state of the art / José Manuel Hernández-Mogollón, José Antonio Folgado Fernández, Paulo Alexandre Oliveira Duarte // European Journal of Tourism, Hospitality and Recreation. - Vol. 5, Issue 2. - Portugal, 2014. - P. 83-102.

2. Бабкін О. В. Спеціальні види туризму / О. В. Бабкін. - Ростов-на-Дону: Фенікс, 2008. $252 \mathrm{c}$.

3. Базові засади менеджменту [Електронний ресурс]. - Режим доступу: https://studopedia.com.ua/1_58563_bazovi-zasadi-menedzhmentu.html.

4. Воскресенська О. Є. Event-менеджмент в управлінні розвитком подієвого туризму / О. Є. Воскресенська, А. М. Фурсов // Молодий вчений. - 2019. - №2. - С. 248-252.

5. Корнілова Н. В. Подієвий туризм в Україні [Електронний ресурс] / Н. В. Корнілова // Географія та туризм. - $2018 . \quad-2$ Режим доступу: file:///C:/Users/Admin/Downloads/gt_2012_22_18.pdf.

6. Олійник В. В. Сучасний стан та перспективи розвитку подієвого туризму на території України [Електронний ресурс] / В. В. Олійник, О.В.Шикіна // Економіка та управління підприємствами. - $2016 . \quad$ - 2 Режим доступу: http://dspace.oneu.edu.ua/jspui/bitstream/.

7. Тищенко П.В. Теоретичні аспекти та розвиток подієвого туризму регіону / П.В. Тищенко // Науковий вісник Ужгородського університету. Серія: Економіка. - 2011. Спецвипуск 33. - Частина 4. - С. 124-128.

\section{References}

1. José Manuel Hernández-Mogollón, José Antonio Folgado Fernández, Paulo Alexandre Oliveira Duarte, 2014. Event tourism analysis and state of the art. European Journal of Tourism, Hospitality and Recreation, 5(2), pp. 83-102.

2. Babkin, O. V. 2008. Spetsial'ni vydy turyzmu [Specialty tourism]. Rostov-on-Don: Feniks.

3. Bazovi zasady menedzhmentu [Basic management principles]. [online] Available at: https://studopedia.com.ua/1_58563_bazovi-zasadi-menedzhmentu.html.

4. Voskresens'ka, O. Ye. and Fursov, A. M., 2019. Event-menedzhment v upravlinni rozvytkom podiyevoho turyzmu [Event- management in event tourism development management]. Young scientist, 2, pp. 248-252.

5. Kornilova, N. V. 2018. Podiyevyy turyzm v Ukrayini [Event tourism in Ukraine]. Geography and Tourism. [online] Available at: file:///C:/Users/Admin/Downloads/gt_2012_22_18.pdf.

6. Oliynyk, V. V. and Shykina, O. V. 2016. Suchasnyy stan ta perspektyvy rozvytku 
podiyevoho turyzmu na terytoriyi Ukrayiny [Current status and prospects of event tourism development in Ukraine]. Business Economics and Management. [online] Available at: http://dspace.oneu.edu.ua/jspui/bitstream/.

7. Tyshchenko P.V. 2011. Teoretychni aspekty ta rozvytok podiyevoho turyzmu rehionu [Theoretical aspects and development of event tourism in the region]. Uzhgorod University Scientific Bulletin. Series: Economy, 33(4), pp. 124-128.

\section{УДК 579.67:616-099(045)}

DOI: 10.31339/2617-0833-2019-2(27)-17-21

\section{БІОЛОГІЧНІ ВЛАСТИВОСТІ ЗБУДНИКІВ ХАРЧОВИХ ТОКСИКОІНФЕКЦИЙ}

Кондрат'єва О. О., Черевач Н. В., Дрегваль О. А., Скляр Т. В.

\section{BIOLOGICAL PROPERTIES OF CAUSES OF FOOD TOXIC INFECTIONS}

Kondratieva Oksana, Cherevach Natalia, Drehval Oksana, Skliar Tetyana

Мета - провести моніторинг поширення збудників харчових токсикоінфекцій серед населення м. Кам'янське. Методи дослідження: бактеріоскопічні, бактеріологічні та серологічні. Одержані висновки та їх новизна: показано динаміку поширення збудників харчових токсикоінфекиій серед населення м. Кам'янське за період 2015-2017 роки, встановлено видовий склад основних збудників захворювань. Результати досліджень можуть бути застосовані для розробки профілактичних заходів щзодо попередження розповсюдження харчових токсикоінфекиій у м. Кам'янське.

Ключові слова: збудники харчових токсикоінфекиій, сальмонели, бактеріологічні методи діагностики, фактори патогенності.

The object of research was frequency identification and biological of properties of bacteria isolated from patients with foodborne diseases. Methods of research: bacterioscopic, bacteriological and serological.The purposes of work was to monitor the spread of foodborne pathogens among the population of Kamianske. The work is interesting for students of biological specialties and doctors of bacteriological laboratories.

1. A study of 60 samples of biological material showed that 25 samples were not contaminated with gut bacteria, 28 contained E. coli, 1 - Salmonella typhimurium, 2 - Salmonella enteritidis, 1 -Shigella flexneri, 2 - Proteus vulgaris, 1 -Proteus myxofaciens.

2. In the study of residues of food consumed by patients before the onset of symptoms of foodborne toxic infections, it was found that out of 115 samples contaminated bacteria were 78. Of these, 54 contained E. coli, 4 - Salmonella typhimurium, 9 - Salmonella enteritidis, 3 - Shigella flexneri, 5 - Proteus vulgaris, 3 -Proteus myxofaciens. Meat and dairy products accounted for the largest share of infected food.

3. The analysis of the frequency of detection of food toxic infections increased during 20152017, reaching its maximum in 2017 (928 cases).

4. The incidence of foodborne toxic infections have a clear frequency: the maximum number of cases detected was in August and September: 127 and 118 cases, respectively (for 2016).

Key words: Pathogen of foodborne diseases, salmonella, bacteriological methods of diagnostics, factors of pathogenity.

Харчові токсикоінфекції - група широко розповсюджених захворювань. Зростання числа підприємств громадського харчування при недотриманні працівниками правил особистої гігієни, зберігання напівфабрикатів і готових страв, термінів і умов реалізації 